„Niech zdrów czyta, ale wesoło..."

- dydaktyczna funkcja komizmu w wybranych satyrach Gracjana Piotrowskiego

Alicja Lewandowska 
nAPIS Seria XIV 2008

\author{
Alicja Lewandowska
}

\title{
„Niech zdrów czyta, ale wesoło...” - dydaktyczna funkcja komizmu w wybranych satyrach Gracjana Piotrowskiego
}

Ks. Gracjan Piotrowski (w zakonie: Gracjan od św. Jana Chryzostoma, 1735-1785) Ybył kaznodzieją, satyrykiem i publicystą okresu Oświecenia, twórcą należącym do środowiska literackiego zakonu pijarów. Był również nauczycielem w szkołach pijarskich, między innymi w Podolińcu, Wieluniu, Łukowie, Łowiczu oraz w Collegium Nobilium w Warszawie. Do jego dorobku literackiego zaliczają się głównie lacińskie mowy, kazania, rozprawy i artykuły ogłaszane w „Monitorze” oraz satyry.

Jego pierwszy i jedyny zbiór satyr ukazał się bezimiennie w 1773 roku pod tytulem Satyr przeciwko zdaniom i zgorszeniom wieku naszego tom I za powodem „Satyra” Jana Kochanowskiego, książęia naszych poetów, który się na końcu satyr kładzie. Oprócz 25 satyr w zbiorze tym zamieszczono utwór Adama Naruszewicza Chudy literat i dzieło Jana Kochanowskiego Satyr albo dziki máz. Swoje satyry kieruje autor przede wszystkim do młodzieży; były one dla niego kontynuacją pracy dydaktycznej. Utwory te mają dużą wartość jako ciekawe świadectwo ówczesnych obyczajów. Niektóre z nich (pięć — późniejsza satyra I, II, III, VII i VIII) przeszły wcześniej przez łamy „Monitora”. Podczas przygotowywania tekstów do wydania drukiem pisarz poprawial je, skracał lub wydłużal, zmieniał imiona bohaterów oraz niektóre realia obyczajowe na bardziej wymowne. W satyrach daje się zauważyć dość ciekawe zróżnicowanie pod względem przedstawionych typów satyrycznych. Są wśród nich: człowiek, który stracił majątek, oszukany kochanek, szlachcic-nieuk, żołnierz samochwał, grymaśnik, leń-ospalec, nieuczciwy polityk, skąpiec, ekonomista-chimeryk, nieuczciwy palestrant-sędzia, libertyni i mędrkowie oraz nieuczciwi gazeciarze.

Przeglądając poszczególne utwory, można dojść do wniosku, że Gracjan Piotrowski dość często korzystał z Mów francuskiego pijara Bernarda Guillelmina (w zako- 
nie: Bernard od św. Ludwika, 1693-1755), ponadto z twórczości Horacego i włoskiego autora-konfratra, Paulina Chelucciego (w zakonie: Paulin od św. Józefa, 1682-1754). Ignacy Chrzanowski pisze:

jednakże jego teksty mają treść ściśle narodową; choć zaczerpnął od swoich mistrzów bajki i przykłady historyczne, to jednak najważniejsza dla pisarza była własna obserwacja życia polskiego społeczeństwa ${ }^{1}$.

Często również autor wykorzystuje przykłady z mitologii, opatrując swoje teksty przypisami. Podstawową formą podawczą jest monolog narratora, rzadziej dialog.

W satyrach Gracjana Piotrowskiego z jednej strony mamy często do czynienia z dydaktyzmem o podłożu kaznodziejskim oraz częstymi zwrotami do młodzieży (np.: „wy, zacna młodzi, która jesteś mi na celu"). Poeta nie ukrywa jednak, że jego posłannictwo ma szerszy zasięg i polega na naprawie moralności współczesnego mu społeczeństwa i wszystkich jego przywar; swoją twórczość traktuje, jak sam mówi, jako „namiestniczy urząd kaznodziei”.

Konwencją pisarską dość często pojawiającą się w satyrach Gracjana Piotrowskiego jest komizm, związany zwłaszcza z przedstawianymi postaciami. Ma on przede wszystkim funkcję dydaktyczną, której konsekwentnie trzyma się autor w całym zbiorze. Spróbujmy więc przyjrzeć się dokładniej wybranym typom satyrycznym, które poeta przedstawia w swoich utworach.

W satyrze I Na zbytki stotowe, garderobne i na towy kosztowne, które przyprowadzaja do nędzy potomstwo postać mówiąca-narrator opowiada, jak pewnego dnia wybierał się do Piotrkowa, aby uczestniczyć w posiedzeniu Trybunału. Po drodze spotyka szlachcica nader mizernego, ale i komicznego wyglądu, idącego boso i bez czapki. Ów nieszczęśnik przyjmuje zaproszenie do kolaski, po czym nawiązuje się rozmowa. Od słowa do słowa opowiadający dowiaduje się, iż źle wyglądający człowiek, mimo że pochodzi z dostojnego rodu, jest całkowicie zrujnowany. Nieszczęśnik plastycznie opisuje wygląd wspaniałego majątku jego ojca, którego wspomina $\mathrm{z}$ wielkim rozrzewnieniem, i wylicza, jak wielki był kiedyś jego stan posiadania: pieniądze, „wioski intratne”, „suknie, cugi, kolaski, stodoły”, młyny, „osiemdziesiąt tysięcy tynfami”. Następnie czytelnik ma okazję przekonać się, dlaczego ów imponujący majątek topniał w zastraszającym tempie:

Żonki też krotofilne na swe andryjany,

$\mathrm{Na}$ szusty, saki, roby, szlafraki, robrany,

Na mankiety, manele, koronki, salopy,

Wyciągnęły z spiklerzów korce, $z$ stodół snopy².

${ }^{1}$ I. Chrzanowski, Ksiadz Gracjan Piotrowski i jego Satyr, „Biblioteka Warszawska” 1902, t. 3, s. 515.

2 [G. Piotrowski], Satyr przeciwko zdaniom i zgorszeniom wieku naszego tom I..., Warszawa, druk. Pijarów, 1773 , s. 3 (sat. I, w. 59-62). 
Autor, przytaczając opowieść nieszczęsnego szlachcica, na zasadzie kontrastu zestawia ze sobą warunki jego życia w czasach dobrobytu i biedy. Pod koniec tekstu opowiada również o podobnych wypadkach utraty majątku, chcąc pocieszyć swego rozmówcę. Wreszcie w dalszej części satyry, jak miał często w zwyczaju, kieruje swe słowa do młodzieży, jako jej wychowawca. Przestrzega młodych przed pochlebcami, próżniakami, którzy trwonią majątki i stanowią przez to zły przykład. Przestrogi te ilustruje wymownymi obrazkami, a gromi i laje tych, którzy żyją ponad stan, hulają, biesiadują.

Bohaterem drugiej ze swoich satyr, noszącej tytuł Na młodego uplątanego $w \dot{z}$ yciu rozpustnym, a potym przymuszonego żenić się nie wedtug kondycyi i wychowania swego, Piotrowski uczynił młodzieńca o bardzo mizernej fizjonomii: „zmienionego cale w szpetnego lemura". Okazuje się, że przyczyną tak zlego wyglądu chłopca jest chorobliwa miłość do „Nigryny, córki praczki i ojca oszusta”, która to Nigryna omotała go całkowicie i sprawiła, że życie mu obrzydło. Z rozmowy możemy wywnioskować, że młody człowiek był dawniej uczniem szkoly pijarskiej. Następnie bohater opowiada, w jaki sposób wkradał się w łaski podstępnej kobiety, brnął coraz dalej w chorobliwym związku; autor próbuje mu pomóc, powołując się na jego wiarę i Biblię, jednak Aleksy zaczyna „właśnie jak lew strzałą lub kulą przeszyty ryczeć od żalu” i nie docierają do niego żadne argumenty. Wreszcie dowiadujemy się, że po pewnym czasie nieszczęśliwy kochanek „zakończył żywot”. W dalszej części satyry autor przygląda się dokładnie Nigrynie, będącej typową modną damą. Opis ten ma na celu ostrzeżenie młodych przed znajomością z podobnymi osobami:

\section{[...] Nigryna portretem}

Niech będzie, wszystkie jednym rządzą się sekretem.

Cały posag jej w twarzy, a cnota w języku,

Stać w oknie przez dzień cały jakby na przesmyku,

Wabić na lep i w skryte łapać głupich sidła,

Jak lalka malowana, upstrzona w piększydła,

Przejęta perfumami. [...]

Patynki złotem tkane, robranik niewąski,

Jak ląka w kwiat rozwiły, ze złota podwiązki

W dyjamenta okute, szyja, ręce, uszy

Są to zdarte z niewinnych piórka, aż do duszy ${ }^{3}$.

Kolejna z satyr Gracjana Piotrowskiego wydana w zbiorze z 1773 roku Na chwalce próżnego dawnego gustu nauk, potępiającego lepszy gust $i$ oświecenie wieku teraźniejszego przedstawia postać szlachcica-nieuka, sarmaty. Jest to jeden z najlepszych tekstów w zbio-

${ }^{3}$ Ibidem, s. 10 (sat. II, w. 129-135, 139-142). 
rze. Pisali o nim między innymi Ignacy Chrzanowski oraz Tadeusz Mikulski ${ }^{4}$. Według pierwszego z badaczy, „tej satyrze zawdzięcza Naruszewicz pomysł do świetnej rozmowy glupiego szlachcica z księgarzem w Chudym literacie"s. Autor-narrator opowiada, że pewnego dnia siedział sobie w Bibliotece Załuskich w Warszawie. Zainteresowało go wówczas szczególnie dzieło Frycza-Modrzewskiego „o rzeczypospolitej zbawiennej odnowie”, gdy nagle skupienie nad książką przerwało mu wejście dziwnej postaci:

Aż wchodzi słuszny wąsacz z pacholiki dwoma,

Czapka jeździ rogata po uszach, rękoma

Sieje, wąsy swe muszczé.

Od słowa do słowa między narratorem a szlachcicem nawiązuje się rozmowa, w której wąsacz wykazuje się niezwykłą ciasnotą umysłową, utożsamia bowiem Herodota $z$ Herodem. Zdziwiony, a nawet tym zgorszony, wykształcony pijar przysuwa się blizej i próbuje go namówić mimo wszystko do przeczytania dzieła Herodota; roztacza przed swym rozmówcą niewątpliwe zalety historii jako „życia nauczycielki”. Na próżno, bowiem ignorant rozgląda się po półkach za herbarzem. Wreszcie w rozmowie pojawia się temat ówczesnych szkół. Szlachcic-nieuk wyraża swą negatywną opinię na temat uczenia się przez współczesną młodzież języków obcych.

W satyrze tej atak pijara skierowany jest przeciw nieuctwu i zacofaniu społeczeństwa. Parodiuje on założenia dawnej edukacji i obskurantyzm czasów saskich. Mimo wszystko jednak postać wąsacza w „czapce rogatej” jest opisana z dużą dozą sympatii i pobłażania.

Kolejnym ciekawym typem satyrycznym jest przedstawiony w satyrze $\mathrm{V}$ żołnierzsamochwal. Satyra nosi tytul: Na chwalce $z$ dziet rycerskich fatszywych, zmyslonego junaka, bez karności i trybu żotnierza. Postać ta spokrewniona jest w pewien sposób z Papkinem z Zemsty Aleksandra Fredry. Sam Piotrowski przyznaje, że podobnego bohatera opisuje laciński poeta Plautus w jednej ze swoich komedii. Już pierwsze wersy utworu pokazują tchórzliwego rycerza w karykaturalny, przejaskrawiony sposób:

Pałasz swój do słonecznych przyrównal promieni,

Dobywa go, rzuca się, ślini i rumieni [...]

Kiedyż pocznie wyliczać swoje w świecie bitwy,

Imanie nieprzyjaciół, utarczki, gonitwy,

Jak na jedne kaszlnienie zatrwożeni cali,

Gdyby snopki, lękliwi żołnierze padali,

${ }^{4}$ T. Mikulski, Ze studióu nad Ośuieceniem, Warszawa 1956, s. 158-184

5 I. Chrzanowski, Ksiądz Gracjan Piotrowski..., op. cit., s. 97.

${ }^{6}$ [G. Piotrowski], Satyr przeciwko zdaniom i zgorszeniom wieku naszego tom I..., op. cit., s. 13 (sat. III, w. 17-19). 
Jak wielu swoim zdeptal, stratowal rumakiem, Nieprzyjacielem pola zasiał gdyby makiem,

Piętnaście głów zlatało na przycięcie jedno -

O czcza gadatliwości, o fortuno biedno!?

Autor poufale, a zarazem ironicznie, nazywa bohatera „Hektorem”, który zwłaszcza przy butelce węgrzyna jest szczególnie gadatliwy, zaś jego bitewne czyny znajdują odzwierciedlenie jedynie w słowach. Komizm tej postaci ujawnia się szczególnie w opisie ucieczki przed nacierającym nieprzyjacielem.

Tekst jest tym bardziej interesujący, że autor zawarł w nim bogaty w porównania i onomatopeje obraz bitwy, widzianej oczyma żołnierza-samochwała, co czyni go komicznym:

Gdy bomby jako dynie latają ogniste,

A kartacze jak węże snują się siarczyste,

Kul jak gradu na placu, i kto zechce wierzyć,

Można by je korcami lubelskimi mierzyć.

Przedtym sztych, sztych! z daleka, chlust, chlust! trochę blizéj,

Usunąl się, uskoczył i podbiegł, kto chyży.

Ale teraz - brum, brum, brum, tra, tra! huczą silnie,

Nie ustrzeżesz się ognia, chociażbyś chciał pilnie.

Jam garścią kule zmiatał jako groch ze ściany,

A raz tak byłem zewsząd w kartacze zmatany,

Jak w powrósła, ledwom co nie zemdlał, do licha,

Już się dusza w ramionach utaiła cicha ${ }^{8}$.

W utworze krytykuje się brak poczucia karności w ówczesnym wojsku oraz szerzenie się w czasie wojny rozbojów z udziałem żołnierzy; satyra poświęcona jest zatem sprawom niezwykle istotnym dla współczesnego Piotrowskiemu społeczeństwa, mimo jej efektownych, zabarwionych komizmem fragmentów.

Współcześni autorowi kodyfikatorzy stylu i języka zarzucali mu często rubaszny, nazbyt potoczny styl i dosadne słownictwo. Opinie te doskonale potwierdza juz początkowy fragment satyry VIII Na leniwego $w$ interesach cudzych $i$ swoich, $i$ wielkiego niechluja okoto siebie, gdzie poeta pisze:

Kuryjo był Nomentan głupiec jako sadło,

Brzuchaty jak kadź; co dzień, skoro się najadło,

Ożłopało, na łóżko walił się jak bela,

${ }^{8}$ Ibidem, s. 27 (sat. V, w. 109-120). 
Chrapi, sapi, ledwo się gardziel nie rozdziela, Bo nie myślał o niczym?

Postać swojego bohatera zaczerpnąl pijar z "poetów dawnych" i nadał mu imię Lentul. W tekście wielokrotnie i drobiazgowo analizuje jego cechy charakteru: lenistwo, zamiłowanie do trunków. Nieco dalej dowiadujemy się, że bohater piastuje dość wysokie stanowisko: jest starostą grodzkim, ale zaniedbuje swoje obowiązki. Pisarz ironicznie wskazuje, że na taką postawę Lentula wpłynęły modne w tamtych czasach książki o przedziwnych tytulach, np. Stonecznik duchowny, Do nieba drabina o stu szczeblach cnót świętych, Danina mitości.

Następnie w satyrze spotykamy doskonały, przesycony humorem, wręcz karykaturalny opis leniucha:

Kindybał nieforemny, opadłe wąsiska,

Kontusz leży jak płachta, pas brzucha nie ściska.

Wargi i brwi obwisłe, gęba otworzona,

Tak że by mógł niedoperz wlecieć albo wrona;

Krok jak klaczy tatarskiej, śmiech głośny, tabaki

Pełno po piersiach; ręce jakby marmur jaki

Od ucierania nosa błyszczą się, a włosy

Nie wiem z jakiej przyczyny strzelają w niebiosy ${ }^{10}$.

Podobnie komiczny jest opis gospodarstwa, w którym służba, niedopilnowana przez właściciela, kradnie dobytek i nie wypełnia swoich obowiązków. Okazuje się, że przyczyną takiego stanu rzeczy jest odkładanie wszystkiego do jutra: „pomyślemy dość jutro", ,jutro temu poradziem".

Wspomniany wyżej tekst jest dość ciekawy, mimo rozwleklej pierwszej części. Wykorzystano w nim przede wszystkim komizm postaci, również komizm słowny, zaś bohater przedstawiony jest karykaturalnie, $z$ dużą dozą drwiny, a jednocześnie pobłażania.

Ogólną cechą twórczości literackiej czasów stanisławowskich były bardzo częste nawiązania do upadku moralnego społeczeństwa z jednoczesną gloryfikacją czasów dawnych. Zgodnie z tymi założeniami we wstępie satyry X Na polityka tego wieku, kłamcę dumnego $i$ cata doskonatość $w$ minie i chytrościach pokładającego Gracjan Piotrowski przedstawia swojego bohatera, którym okazuje się polityk-mędrek. Wstępem do opisu tej postaci uczynił autor streszczenie bajki Ezopa Żaba i wót:

Dumny człowiek i w minie górnej, chociaż słaba

Glowa, gdy się napuszy, jak Ezopa żaba,

Wołu widząc rosłego, ten się mądrym uda

9 Ibidem, s. 38 (sat. VHI, w. 1-5).

${ }^{10}$ Ibidem, s. 41 (sat. VIII, w. 105-112). 
I mogący panować nad mnogością luda.

Udatność, zręczność, mody przestrzeganie dadzą

Bieglego polityka imię, wszelką władzą

$\mathrm{Z}$ innych się natrząsania, swawolnej krytyki

I hardego mięszania najskładniejsze szyki ${ }^{11}$.

W dalszej części utworu poeta drobiazgowo analizuje przedstawioną postać, na przykład jej sposób mówienia:

A gdy mówi, tak gębę odyma, odmucha,

Rzeklbyś, że z niej wypadnie wielka zawierucha,

I dobrze, bo przynajmniej, kiedy głowa pusta,

Napuszyć nie zawadzi, chociaż próżne usta ${ }^{12}$.

Główną cechą polityka-mędrka jest egoizm, wywyższanie się nad innych, mimo własnego prostego pochodzenia. Poeta w ośmieszający sposób wypowiada się o bohaterze, który uważa, że „cały świat prócz niego zepsuty”. Okazuje się, że ten modnie ubrany polityk to człowiek wygodny, sprytny i przebiegły, choć na pozór układny. Opisywane cechy postaci są również komiczne:

A czasem, gdy go jaka myśl górna napusza,

Posunie w tyl na głowę raptem kapelusza,

Podgarnie włosów, czoło, stolicę odkryje

Pychy, w której się roją szumne fantazyje

I planty jak bałwany miotają się w głowie.

Dopieroż go posłuchać, jak swe pieści zdrowie:

Niech go łokieć lub mały paluszek zaboli,

Zaraz felcera trzeba ${ }^{13}$.

Niewątpliwy dydaktyzm satyry podkreśla zakończenie utworu, zawierające przestrogę kary boskiej, która niechybnie spotka złych ludzi, podobnych w swym postępowaniu politykowi.

Oryginalnym imieniem Flawiusza obdarzył autor bohatera satyry XV Na ekonomiste, chimeryka śmiesznego $w$ swoich plantach i dyspozycyjach, który uległ zagranicznym doradcom - frantom i szalbierzom, cwaniakom i oszustom, i zaczął wprowadzać w swoim gospodarstwie różne dziwne, rzekomo postępowe i nowoczesne pomysły. Satyryk porównuje te przedsięwzięcia do dziecinnych budowli:

${ }^{11}$ Ibidem, s. 46 (sat. X, w. 19-26).

12 Ibidem, s. 48 (sat. X, w. 69-72).

${ }^{13}$ Ibidem, s. 52 (sat. X, w. 215-222). 
Śmiech nam czynią dziecinne częstokroć budowia

$\mathrm{Z}$ piasku, gliny i kartek, gdy się na kształt mrowia

Wysypią do zabawki i na tym czas ludzą,

Jeden stawia, a drugi psuje sprawę cudzą.

Starszych ludzi, roztropnych to dzieciństwo bawi,

Kiedykolwiek patrzą się na ten śmiech ciekawi.

Podobne nam otwarzasz teatrum i scenę

W tych plantach, rozrządzeniach, do których masz wenę

I niespokojne zawsze, Flawijuszu miły,

Przywiązanie... ${ }^{14}$

Poddani „chymeryka” opuścili wieś ze strachu przed jego eksperymentami, więc postanowił założyć miasto. Proces budowy rozpoczął się od przygotowania projektu, który niestety okazał się dziwny i absolutnie niepraktyczny. Autor wróży budowniczemu niewesołą przyszłość:

$$
\text { [...] w plantach tylko cala }
$$

Twa zabawka i rozkosz. Pustki są widoczne

Po chałupach zrzuconych i polach, co roczne

Rodzicom twym i dziadom wydawały plony,

A na miejsce twej straty słup tylko stawiony

$Z$ tablicą o wolnościach. Coś mi serce wróży

(Nie chcę, żeby prawdziwie), iż nie będzie róży

$\mathrm{Z}$ tego ciernia, nie będzie ryb $\mathrm{z}$ tego polowu,

Sam tylko śmiech zostanie jak $z$ innych spraw znowu ${ }^{15}$.

Pod koniec satyry autor ponownie powraca do wątku dziecinnych budowli, zaś zajęcie Flawiusza nazywa „dzieciństwem”, „szaleństwem” oraz „próźniacką zabawą”. Czytelnika zaś przestrzega przed podobnymi praktykami, podkreślając szkodliwość społeczną zagranicznych doradców.

Jednym z ciekawszych tekstów w zbiorze z 1773 roku jest satyra XXI Na rzqdców i na starszeństwo zmyślonej cnoty, a w rzeczy samej pogorszycielów i uciemięźliwych opiekunów. Utwór otwiera zabawna opowieść o białym kocie - nieprzyjacielu gryzoni, który byl „okrutny i frant razem” i skutecznie tępił w gospodarstwie wszystkie myszy. Wreszcie jedna z nich postanowiła skończyć z kocimi rządami:

Na koniec, kiedy wszystkim dogrzal już do sedna, Gdy ich na pół wytępił, odezwie się jedna:

${ }^{14}$ Ibidem, s. 73 (sat. XV, w. 1-10).

${ }^{15}$ Ibidem, s. 75-76 (sat. XV, w. 86-94). 
„Siostry nieszczęsne, czas już poradzić o sobie!

A długoż w tej sromotnej jęczeć możem dobie?”.

Zgoda zatym stanęła, by sejm był zwołany.

Zamek radom obraly w dziurze między ściany,

A gdy się tam już liczna zebrała gromada,

Każdy swój projekt wnosi, obstaje i gada.

Przecięż na to przystały wszystkie, aby z dziury

Nie puszczać pojedynczo na zgubę ni któréj,

Lecz co dzień po dwie tylko wysłane być miały,

By znosily dla innych różne wiktuały,

Inne zaś zewsząd wały, szańce sypią wkoło,

Tamując wchód kotowi, pracują wesoło ${ }^{16}$.

W taki to sposób myszy doprowadziły do sytuacji, w której kot stał się „mizernie schudzonym, / Spadł z ciała, ledwo chodzi i kiwa ogonem". I stało się, że będąc bardzo słabym i szukając jedzenia po półkach, wpadł w „czernidło czarne” i z białego kota stał się czarnym, do złudzenia przypominającym mnicha.

Myszy, ujęte tak nagłą odmianą dawnego prześladowcy, postanowiły wyjść z ukrycia i pogratulować „tak świętego życia heroicznego”. Kot tylko na to czekał: zaczął łapać, dusić i mordować bezbronne myszy:

Na ten widok okropny jedna placze, woła: „Tyranie, takiżeś ksiądz? takaż to Kościoła Religija? taż to jest duchownych zabawa Drzeć i łupić ze skóry?”. Te słowa oddawa Na odwrót mój ksiądz nowy: „Alboż nie wiesz — prawi -

Że na wszelkie występki księża niełaskawi?

Jeśli was szkodne karzę, czynię sprawiedliwie, Za cóż ludziom płatacie krzywdy nieszczęśliwe?" ${ }^{17}$.

Historia ta jest wstępem do bardzo ostrej krytyki tych, którzy będąc u władzy, wykorzystują swojego stanowiska i niszczą poddanych:

Do was to mowa cała, w srogości nieczuli

Panowie, pod których rząd lud się nędzny tuli,

$Z$ równości i z natury praw będąc wyzuty,

Opieki chce, nie kary, nie srogiej pokuty.

Krew ich ssiecie, żyjecie krwawym onych potem...

${ }^{17}$ Ibidem, s. 109-110 (sat. XXI, w. 85-93). 
Ich trudami, majątkiem, krokiem bystrolotem,

Niszczeniem sił czynicie dla siebie wygodę $[\ldots]^{18}$.

Dalej autor deklaruje się jako obrońca uciśnionego ludu i woła:

$$
\text { O mój Boże, jacy }
$$

$\mathrm{Z}$ tych panów są tyrani! Wybaczam stanowi

Świeckiemu, bo ci w Piśmie i naukach nowi,

Niebywali, lecz prze co stan duchowny święty

Tak obrzydłe za prawa przejmuje wykręty,

Panowanie nad ludem przywlaszczając rowne

$\mathrm{Z}$ pogany $[\ldots]^{19}$.

Pozornie komiczny wstęp stal się w tym utworze pretekstem do uświadomienia społeczeństwu, jak często dochodzi do nadużywania władzy i działania na szkodę poddanych. W utworze autor wielokrotnie powołuje się na przykłady zaczerpnięte z dziejów starożytnego Rzymu, na koniec odwołując się także do Ewangelii wedtug św. Mateusza.

Wszyscy badacze, zajmujący się dotychczas twórczością Gracjana Piotrowskiego, a w szczególności Alina Aleksandrowicz ${ }^{20}$ i Ignacy Chrzanowski ${ }^{21}$, podkreślają, iż temu niesłusznie zapomnianemu, świetnemu twórcy literatury oświeceniowej, powinno się przywrócić należne mu miejsce wśród pisarzy tego okresu. Warto również pamiętać o tym, że w swoich utworach zawarł on cenny materiał dotyczący obyczajowości czasów, w których żyl. Do niewątpliwych walorów jego twórczości, oprócz żywego i barwnego sposobu obrazowania, należy zaliczyć również jego szczególne poczucie humoru i autentyczne zaangażowanie. Z drugiej jednak strony jego utwory cechują zbyt rubaszny, dosadny język, przesadna dawka kaznodziejstwa, niepotrzebna drobiazgowość i skrupulatność w przedstawianiu wad i przywar. Mimo to warto poznawać te niezwykle interesujące teksty, zaangażowane w poprawę obyczajów.

Zamiast podsumowania warto przytoczyć zamieszczone w zakończeniu pierwszego tomu satyr słowa autora, którymi wyraził własne zdanie na temat posłannictwa swej twórczości satyrycznej:

\footnotetext{
${ }^{18}$ Ibidem, s. 107 (sat. XXI, w. 107-112).

${ }^{19}$ Ibidem, s. 109 (sat. XXI, w. 166-172).

${ }^{20}$ Zob. A. Aleksandrowicz, $Z$ badań nad twórczościa satyrycznq Gracjana Piotrowskiego, „Annales Universitatis M. Curie-Skłodowska", seria F, vol. 13: 1958, Lublin 1961, str. 233-263.

21 Zob. I. Chrzanowski, Ksiądz Gracjan Piotrowski i jego Satyr, „Biblioteka Warszawska” 1902 t. 3, s. 503-531; t. 4, s. 93-120.
} 
Honorowi i cnocie razem z przymiotami

Poświęcam tę skwapioną, obyczajną pracę,

Za którą niech wdzięczności daniny nie tracę.

$Z$ występkami wojuję, ludzi rodzaj równy,

Kocham, wielbię, szacuję [...]

Uschnę z żalu, jeżeli występki nie zginą

Ożyję, jeśli z wiatrem ucieką... ${ }^{22}$

22 [G. Piotrowski], Satyr przeciuko zdaniom i zgorszeniom wieku naszego tom I..., op. cit., s. 140 (Zakończenie satyr tomu $I$, w. 2-6, 13-14). 